Quality Assurance Practices in the Global Supply Chain: The Effect of Supplier Localization

\author{
Alberto Bayo-Moriones* \\ Corresponding author \\ Department of Business Administration \\ Public University of Navarre, Spain \\ Campus de Arrosadia \\ 31006 Pamplona (Spain) \\ Phone: 34948169377 \\ Fax: 34948169404 \\ Email: abayom@unavarra.es \\ Alejandro Bello-Pintado \\ Department of Business Administration \\ Public University of Navarre, Spain \\ Javier Merino-Díaz-de-Cerio \\ Department of Business Administration \\ Public University of Navarre, Spain
}

\footnotetext{
* The authors acknowledge financial support from the Spanish Ministry of Education and Science project SEJ200766511.
} 


\title{
Quality Assurance Practices in the Global Supply Chain: The Effect of Supplier Localization
}

\begin{abstract}
This paper deals with quality management practices in the global supply chain. More specifically, the association between the geographical location of suppliers (within a country or in low labour cost countries) and quality assurance practices is analyzed. Three hypotheses are proposed and tested using a sample of 401 Spanish manufacturing establishments with at least fifty workers in all industries. The results indicate that plants purchasing a higher proportion of their inputs in low-cost countries are more likely to be certified according to a quality standard. However, no associations have been found between the localization of suppliers and the establishment of close relationships with suppliers in order to assure quality.
\end{abstract}

\section{Keywords}

Quality management, Supply Chain, Supplier localization, Empirical analysis 


\section{Introduction}

In recent decades the supply chain has experienced substantial international expansion as a consequence of market globalization and the increase in competition. In this context, several authors point to the need for a good SCM as a basic tool to remain competitive in the global race (Childhouse et al., 2003). SCM can help to provide a sustainable competitive advantage by improving product performance and service while simultaneously reducing cost (Davis, 1993; Li et al, 2006). Thus, the importance of SCM to business performance in the manufacturing industry has been extensively documented in recent times from several different perspectives such as logistics, marketing, internal organization or integrated information management (Croom and Giannakis, 2004; Kaynak and Hartley, 2008; Yeun, 2008; Thomas, 2008).

Purchasing function is a key business process within SCM (Lambert et al. 1996; Sánchez-Rodriguez et al., 2004). The purchasing function is typically responsible for selecting suppliers, managing long-term contracts, monitoring supplier performance and maintaining close and effective supplier relations. All these activities are also part of the remit of Quality Management (QM) (Kaynak and Hartley, 2008); therefore, the integration of QM and SCM is crucial to company competitiveness (Flynn and Flynn, 2005; Matthews, 2006).

The purchasing function has recently faced significant challenges such as supplier selection so as to achieve efficiency in the relationship between supplier and buyer (Cox, 2001; Florez-Lopez, 2007). Such efficiency is associated with commitment, collaboration and others factors linked to the inter- and intra-organizational dimensions of the management of external relations in global purchasing (Sven et al., 2009). The complexity of these challenges is closely related to the internationalization of the production processes carried out by many manufacturing companies, which no longer source inputs only from firms based nearby in geographical terms, but obtain a large proportion of their supplies from plants located in other countries. The increase in input purchases for Western companies from areas such as Eastern Europe, Central and South America, Asia and North Africa has been especially marked in recent years. The main reason for this phenomenon obviously lies in the low labour costs for production workers in those countries. However, buying in such locations raises some questions regarding product quality. The underdeveloped technology and unskilled workforce usually associated with low cost supply may lead to low quality. How this risk might be dealt with is a problem which purchasing firms must address. In this regard, quality 
management practices emerge as devices that can help firms to ensure that supply quality meets the requirements of competitiveness.

In this context, the aim of this empirical paper is to study the relationship between the localization of suppliers and the use of quality assurance practices. The focus of interest is to analyze whether or not the degree of purchasing in low labour cost countries or in the same country is associated with the implementation of quality management practices. Despite the considerable impact of purchasing function on firm performance (Chen et al., 2004) and the growing importance of firms from foreign countries as suppliers, relatively little research on this issue is to be found in the relevant literature. For this purpose, information from 401 Spanish manufacturing plants with at least fifty workers from all manufacturing industries is analyzed.

The paper is organized as follows: first, a definition of the concept of quality assurance in the context of Global Supply Chain Management is presented; then, the relationship between quality assurance and supplier localization is analyzed, which gives rise to the formulation of hypotheses; in the third section, the data and variables used in the empirical part of the paper are described; the next section is devoted to the results of the empirical test of the theoretical hypotheses; finally, the main conclusions of the paper are explained.

\section{Quality Assurance Practices in the Global Supply Chain}

As mentioned above, many firms have internationalized their purchases. Some reasons for purchasing abroad have to do with the achievement of a competitive advantage related to innovation and quality, which may not be available within the firm or even in the country where the firm is located (Steinle and Schiele, 2008). However, companies also strive to benefit from cross-border, factor-cost advantages through lowwage countries (Alguire et al., 1994; Ettlie and Sethurament, 2002). A typical manufacturing company spends between half and three-quarters of its turnover on purchases such as raw materials, components and semi-manufactured goods (Cammish and Keough, 1991; Dyer et al., 1998). Therefore, purchasing in countries with low labour costs and, as a consequence, at reduced prices may help the firm to achieve lower costs.

However, if additional transport, maintenance or quality costs arise, low input costs may not automatically translate into lower total production costs. ,. In fact, reducing input costs by finding the cheapest partners in international trade does not 
seem to be enough to ensure manufacturing success. In this context, the implementation of quality assurance practices may allow firms to acquire a good quality supply of raw materials and components (González-Benito and Dale, 2001). In this way, companies can respond adequately to the new competitive environment in which factors other than price, such as quality and quick responses to change and deliveries, also play a significant part (Palaniswarni and Lingaraj, 1994; Narasimbhan and Carter, 1998).

Quality assurance practices may be defined as a set of activities and attitudes in the firm that promotes collective involvement to work together in a process of continuous improvement and product and service quality assurance (Gonzalez-Benito and Dale, 2001). One important sub-set centres on finding a supply firm that can provide quality, low-cost goods at the right time. Good management of suppliers is essential for quality because of the substantial impact of raw materials and components on the quality and reliability of the production process (Deming, 1986; Garvin, 1987).

With regard to these QM practices concerning supply quality, one may distinguish between the application of internal and external quality practices; the relationship of each with supplier location is analysed in the following subsections.

\subsection{Internal Quality Assurance Practices and the Localization of Suppliers}

From the internal perspective of quality assurance, the importance of certification systems must be underlined (Dale 1999; Sroufe and Curkovic, 2008). Several studies have analysed the motivations for ISO 9000 implementation (MartínezCosta and Martínez-Lorente, 2008; Nair and Prajogo, 2009), concluding that one of the main reasons is to improve internal operations.

Quality managements systems like ISO 9000 or other more demanding standards such as ISO TS16949 require an organization to ensure that its supplied components meet product specifications. In relation to suppliers, this standard involves correct product definition, including the requirements and verification of products through inspections. ISO 9000 explicitly refers in purchasing to aspects such as supplier evaluation, monitoring of performance, records of acceptable suppliers and a formal written definition of requirements and specifications (Dale, 1999). Through ISO 9000 preparation and registration, an organization can develop its purchasing function more systematically, making SCM a strategic initiative for profitability (Yeung, 2008). Firms that have effectively implemented a system like this one reinforce their control over suppliers and, as a consequence, reduce the faults that can emerge due to defective 
purchased goods. The positive effects of ISO 9000 in relation to suppliers have been shown empirically by Casadesus and de Castro (2005).

When raw materials and components are purchased in low-cost countries, it is reasonable to suppose that plants may to a certain extent mistrust supplier quality. As a result, they may try to exercise greater control. In such cases, the guarantee of quality can be achieved through internal assurance quality practices such as standards that emphasise the monitoring of suppliers. For this reason, so as to address the information and uncertainty that purchasing in low-cost countries can prompt, it may be said that firms which buy such supplies are more likely to have incorporated quality systems of this kind to a greater extent, which leads to the following hypothesis:

H1: internal quality assurance practices are more likely to be implemented when suppliers are located in low-cost labour countries

\subsection{External Quality Practices and the Localization of Suppliers}

In the context of supply management, external quality practices can be defined as the set of activities designed to assure supply quality through a closer and proactive relationship with suppliers. Gonzalez-Benito and Dale (2001) and Gonzalez-Benito et al. (2003) refer to different practices with this goal, some of which aim to promote effective and efficient long-term relationships with a limited number of suppliers. Other practices involve further involvement, through supplier participation in product design and development, problem-solving and process improvements.

Such external practices clearly go beyond the requirements of ISO 9000. However, as Casadesus and de Castro (2005) indicate, firms certified by this standard do not adopt practices such as prioritizing quality and service rather than price or the establishment of agreed quality systems, in spite of regarding them as worthy of application. Moreover, the ISO quality standards ensure only that a quality system exists, but cannot guarantee its functionality within a particular firm or supply chain (Sroufe and Curkovic, 2008).

The implementation of these practices requires the sharing of information so as to establish trust, commitment and collaboration (Fynes et al., 2005). In addition, they can be particularly difficult and costly to introduce when suppliers are located in lowcost countries, for several reasons. First, although quality management has become part of doing business in developed countries, its approaches and techniques are new to many low-cost countries. Moreover, given that frequent and timely communication is 
very important in resolving disputes and aligning perceptions and expectations (Morgan and Hunt, 1994; Fynes et al., 2005), both expenses for regular face-to-face meetings (Skarmeas et al., 2008) and transaction uncertainty (Bello and Gilliland, 1997; Kaufmann and Carter, 2006) rise when the geographical distance from suppliers is too far. In spite of the recent development of new technologies of electronic communication and efficient logistical arrangements, this is still the case (Salmi, 2006; Beheshti et al., 2007; Carvalho and Costa, 2007; Hsu and Wallace, 2007).

In this situation, psychic distance, defined as a sum of factors preventing the flow of information from and to the market (Johansen and Vahlne, 1977), is also a difficult barrier to manage properly. Trade in international markets is marked by different social, cultural, political, technical, and economic dimensions (Terpstra and Sarathy, 2000). Such differences impinge on exchange-partner management practices and styles, with significant implications for the management of cross-border relationships, mainly in aspects relating to the implementation of quality management practices (Johnson et al., 2000; Skarmeas et al., 2008). To overcome these barriers, companies must acquire new foreign market knowledge incrementally and only gradually increase their commitments to foreign operations (Salmi, 2006).

Therefore, despite the fact that firms may have a particular interest in adopting external quality practices in their relations with suppliers, the problems that may arise through such implementation due to differences of many kinds between the partners might lead to a lower incidence of them.

The empirical evidence on external quality practices and supplier location is scarce. One relevant piece of research in this area is the article by Pfohl and Large (1997), in which East-West supply relationships in the agricultural machinery industry is analysed. To establish a successful East-West supplier-customer relationship, participant managers indicated that the most important requirement was a price lower than in Western Europe, but that a quality level comparable to Western Europe was also needed. Deficiencies in supplier quality were cited as one of the main reasons for the failure to establish successful relationships with Central and Eastern Europe.

Therefore, in line with the arguments detailed above, the following hypotheses may be formulated:

H2: external quality assurance practices are less likely to be implemented when suppliers are located in low-cost labour countries; 
H3: external quality assurance practices are more likely to be implemented when suppliers are located in the same country.

\section{Data}

\subsection{Data collection}

The data used in the empirical part of the paper comes from a survey conducted in 2006 in 401Spanish manufacturing plants with more than 50 employees from all manufacturing sectors. The information was collected through personal interviews with a manager at the plant. The manager interviewed was either the plant manager or the operations manager. These positions were selected for interview in order to ensure that the respondents had a broad knowledge of the company as a whole, and of the management of the supply chain in particular. The average length of the interviews was sixty minutes.

For the purposes of the research, a questionnaire was compiled following the methodological recommendations outlined by Nunnally and Bernstein (1984). The questionnaire included questions relating to plant and worker characteristics, work organization, human resources management, technology, production organization and operational performance. An in-depth review of the relevant theoretical and empirical literature was carried out in advance so as to define the different questions (for example, Saraph et al; 1989; Anderson et. al., 1995; Ahire et al., 1996; Merino, 2003; GonzalezBenito et al., 2003).

In order to avoid potential problems of common method variance, several recommendations mentioned in the literature were taken into account in the questionnaire design (Podsakoff et al., 2006). For example, different response formats for the measurement of the variables were applied (five-point Likert scale, zero-to-ten scale, dummy variables, etc). Moreover, the items were based on scales that have been tested and widely used in the literature. The questionnaire was pre-tested through a set of interviews with the managers of fifteen manufacturing plants in order to improve the clarity and content of each measure.

\subsection{Measures}

\section{Quality Assurance Practices}

As mentioned in the theoretical section, the focus is on both internal and external quality assurance practices related to supplier management. The presence of internal 
quality assurance practices is measured through an ordinal variable that identifies the quality standards in accordance with which the plant is certified. This variable takes values from one to four depending on whether or not the plant was certified in a quality standard and the degree of requirements of the quality management system: the higher the score, the more demanding the certification. This variable takes value one if the establishment is not certified; value two if it is certified according to ISO 9000; value three if by another quality standard which is more demanding than ISO 9000; and value four if it is certified both by ISO 9000 and another quality standard that is more demanding than ISO 9000.

In order to capture external quality assurance practices, an indicator comprising five items is used. These items assess on a one (with no supplier) to five (with all suppliers) scale the extent to which the plant strives to establish long-term relationships with suppliers, quality is a key factor in supplier selection, suppliers are periodically evaluated throughout audits, suppliers are actively involved in new product development process, and the plant agrees with suppliers specific quality certifications. These items have been taken from the literature on supplier management from the perspective of quality management (Saraph et al., 1989; Merino, 2003; Bayo-Moriones et al., 2008).

The resulting index for external quality assurance is treated as a formative indicator (Diamantopoulos and Winklofer 2001). In this case, the indicators are causing rather than being caused by the latent variable measured (MacCallum and Browne 1993). "A breadth of definition is extremely important to causal indicators" (Nunally and Bernstein, 1994): thus, a census of indicators is required for a formative specification. Secondarily, the absence of multicollinearity between items has been tested so as to validate the construct (Podsakoff et al., 2006).

Table I reports the mean and standard deviation of the Internal Quality and External Quality measures. The mean value for the first variable comes from $18.7 \%$ plants in the sample with no quality certification, $18.3 \%$ certified only according to ISO 9000, 6.7\% according to a standard more demanding than ISO 9000, and 56.3\% certified by both ISO 9000 and another more demanding quality standard. The table also shows the values of the Variance Inflation Factor (VIF) for all the items in the External Quality Practices index. As recommended, all the values are lower than five, indicating the absence of multicollinearity, which is required for the validity of the index. 


\section{Insert Table I}

\section{Supplier Localization}

Supplier localization is measured by two variables. The first indicates the percentage of raw materials and components purchased by the plant in low labour cost countries, such as Eastern Europe, China, India, etc. The second variable shows the value of this percentage in relation to purchases made in the country where the establishment is located - that is, in this case, Spain.

\section{Control variables}

A number of control variables that are widely deployed in the literature on the determinants of the incidence of quality management have been included in the analysis. Size is measured by the number of workers in the plant (Sila, 2007). Membership of a multinational corporation has also been considered through a dummy variable (Sila, 2007). Competition intensity faced by the plant in the market is measured by an ordinal variable that takes values ranging from one (very low competition) to five (very intense competition) (Merino, 2003).

The use of Advanced Manufacturing Technologies (Dean and Snell, 1996; Beaumont et al., 2002; Bayo-Moriones et al., 2008) is measured by an index that reflects on a zero to ten scale the degree of use of technologies such as Shop floor data capture, ERP, Preventive maintenance software, Bar coding, Artificial vision technology, Automatic Guided Vehicles, Automated warehousing, Computerised numerical control machines, Robotics, Flexible manufacturing cells, CAD/CAM and Laser technology. Finally, the manufacturing strategy adopted by the plant is considered. Dummy variables are used to reflect whether the establishment focuses on quality, cost or another factor (flexibility, innovation, delivery time or service). Fourteen sector dummies have also been included to take into account differences in items purchased between plants.

Table II displays the main descriptive statistics for both supplier localization variables and control variables while Table III shows the correlations for all the variables in the article. The analysis discloses that several significant correlations emerge between the dependent and independent variables described here; these are discussed using multivariate analysis methods in the next section. Moreover, it can be 
observed that membership of a multinational corporation is the only variable related to our origin of purchases variables. In more specific terms, multinationals buy a larger proportion of their supplies in low-cost countries.

\section{Please Insert Table II and Table III}

\subsection{Estimation Method}

The existence or not of association between quality assurance practices and the localization of suppliers was tested using multivariate techniques. In the case of the internal quality assurance variable, ordered probit models have been estimated. For the external quality assurance practices index, ordinary least square models have been performed.

\section{Results}

Table IV and Table V report the results of the models estimated to explain our two dependent variables. Two models have been estimated in each case. The first includes only the two measures relating to supplier localization as explanatory variables, whereas control variables have been added in the second.

The results for the models explaining quality certification indicate that supplier localization is strongly related to the firm's commitment to internal quality in production processes (Table IV). This finding persists when control variables are introduced in the model. Therefore, firms that purchase in low-cost countries to a greater extent show a higher likelihood of having been certified at least with ISO 9000 or even with more demanding standards in order to ensure internal process quality. However, no significant relationship has been found for the percentage of raw materials and components purchased in the home country.

Thus, since quality standard certification is positively related to suppliers located in low-cost countries, the first hypothesis is confirmed. Our findings also show that the implementation of internal quality assurance practices is not related to purchasing inside the country.

Insert Table IV 
Regarding the incidence of external quality assurance practices, no robust association is found with the countries where purchases take place (Table V). Results in the models indicate that there is influence of the purchase of inputs in Spain and the purchase of inputs in low-cost countries on the application of external quality management practices in relation to suppliers. The second model verifies that larger firms with a higher incidence of Advanced Manufacturing Technologies which compete in the market based on quality tend to implement external quality assurance practices more frequently. These results do not support our second and third hypothesis.

\section{Insert Table V}

Summing up, supplier location is associated with the quality management of suppliers, but only from an internal perspective. Previous studies that have dealt with similar issues have highlighted the difficulties involved in establishing long term commitments and effective collaborative relationships with suppliers located in lowcost countries (see Pfohl and Large, 1997). Our results, however, suggest that these obstacles also arise when supplies are purchased in the home country or in a developed country.

\section{Conclusions}

This paper deals with quality management practices used in a global supply chain. Specifically, the association between the geographical location of suppliers and the quality assurance practices used to deal with them has been analysed. This relationship has been tested using data from a survey carried out in 401 Spanish manufacturing plants with at least 50 workers.

In recent years, the elimination of barriers to international trade and the extension of free trade areas, such as the European Union, have enabled many firms to avail of different options in purchasing production inputs. In this sense, in response to the more competitive market environment, and also given the marked importance of raw materials and components in the total costs of products, many firms have sought out their inputs in low-cost countries. Despite this growing phenomenon and the significance of the purchasing function in firm performance, no papers have as yet addressed this particular topic in the specialized literature. 
The results indicate that only the implementation of internal quality practices is related to supplier localization, mainly when they are located in low-cost countries. Companies that purchase from suppliers located in low-cost countries put into practice the requirements that quality systems establish in relation to the purchasing process. As a result, the endorsement of the products purchased is emphasized, followed by product verification on receipt.

With regard to external quality practices, their implementation might be expected to be easier when suppliers are located nearby. However, the results clearly show that firms implement these external practices depending on their size, the technological complexity of the process or the strategic orientations toward the quality, rather than as a function of supplier localization.

These findings are very significant for industrial policy. Companies that purchase in international markets so as to reduce input costs work hard on quality certifications to ensure the internal quality of their processes. Undoubtedly, these are good practices. Nevertheless, the results show that the establishment of external quality practices is more complex for such companies. In this regard, given that there is consensus about the need to make a concerted effort to establish commitment and collaborative relations with suppliers to achieve improvements in quality and competitiveness for all the firms that comprise the vertical chain, the existing high barriers to the development of these vertical relationships should be overcome. Therefore, the authorities should encourage collaboration between firms, helping them to facilitate direct relationships with suppliers. This process is costly and its profitability is not visible in the short term; however, it is necessary to ensure progress towards improvement and competitiveness. For example, companies might be helped to incorporate qualified young people in their workforces, who would be quite capable of effectively carrying out the activities relating to suppliers.

That this study is not free of limitations related to the characteristics of the dataset should also be noted. For example, the cross-sectional nature of the data precludes inferences regarding robust causality relationships. Further study is required to provide more in-depth analysis on the ways in which the relationships described here may work. That is, further theoretical and empirical work is required to define mediating variables between supplier localization and the use of quality assurance practices. In addition, the role of antecedent variables of both variables should be explored. In this regard, Kraljic's model may provide useful insights regarding the role of product type. Whether 
the items involved are strategic, bottleneck, leverage or noncritical may influence the firm's choice of where to buy them and the quality assurance approach to be followed. These results underscore the need to study the complex relations between quality management and internationalization in detail. The country of origin of purchases is a variable that is not considered in the main quality management models. However, this paper shows that it plays an important role in the decisions taken to achieve quality assurance.

\section{References}

Ahire, S., Golhar, Y. and Waller, M., "Development and validation of TQM implementation constructs”, Decision Sciences, 1996, 27, 23-56.

Alguire, M., Frear, C. and Metcalf, L., “An examination of the determinants of global sourcing strategy”, Journal of Business and Industrial Marketing, 1994, 9, 62-74.

Anderson, J., Rungtusanatham, M. and Schroeder, R., “A theory of quality management underlying the Deming management method”, Academy of Management Review, 1994, 19, 472-509.

Bayo-Moriones, A.; Bello-Pintado, A., y Merino-Díaz-de-Cerio, J., “The Role of Organizational Context and Infrastructure Practices in JIT Implementation”, International Journal of Operations and Production Management, 2008, 28, 10421066.

Beaumont, N., Schroder, R. and Sohal, A., "Do foreign-owned firms manage "advanced manufacturing technology” better?”, International Journal of Operations \& Production Management, 2002, 22, 759-771.

Betheshti, H., Hultmang, M., Jung, M. Opoku, R, and Salegi-Sangari, E., "Electronic supply chain management applications by Swedish SMEs”, Enterprise Information Systems, 2007, 1, 255-268.

Bello, D. and Gilliland, D., "The effect of output controls, process controls, and flexibility on export channel performance”, Journal of Marketing, 1997, 61, 22-38.

Cammish, R. and Keough, M., “A strategic role for purchasing”, The McKinsey Quarterly, 1991, 3, 22-39.

Carvalho, R. and Costa, H., “Application of an integrated decision support process for supplier selection”, Enterprise Information Systems, 2007, 1, 197-216.

Casadesús, M. and De Castro, R., "How improving quality improves supply chain management: empirical study”, The TQM Magazine, 2005, 17, 345-357. 
Chen, I., Paulraj, A. and Lado, A., "Strategic purchasing, supply management, and firm performance", Journal of Operations Management, 2004, 22, 505-523.

Childhouse, P and Towill, D., "Simplified material flow holds the key to supply chain integration”, Omega, 2003, 31, 17-27.

Cox, J., "Managing with power: strategies for improving value appropriation from supply relationship”, The Journal of Supply Chain Management, 2001, 37, 42-47.

Croom, S. and Giannakis, M., "Towards the Development of a Supply Chain Management Paradigm: A Conceptual Framework”, The Journal of Supply Chain Management, 2004, 10, 27-37.

Dale, B., Managing Quality, 1999, Oxford, Blackwell.

Davis, T., "Effective Supply Chain Management”, Sloan Management Review, 1993, 34, $35-46$.

Dean, J. and Snell, S., “The Strategic Use of Integrated Manufacturing: An Empirical Examination”, Strategic Management Journal, 1996, 17, 459-480.

Deming, W., "Improvement of Quality and Productivity through Action by Management”, National Productivity Review, 1981, Winter, 12-22.

Diamantopolulos, A. and Winklhofer, H. "Index construction with formative indicators: an alternative to scale development”, Journal of Marketing Research, 2001, 38, 269-277.

Dyer, J., Cho, D. and Chu, W, “Strategic supplier segmentation: the next best practice in supply chain management”, California Management Review, 1998, 40, 57-77.

Ettlie, J. and Sethuraman, K., "Locus of Supply and Global Manufacturing", International Journal of Operations and Production Management, 2002, 22, 349370

Florez-Lopez, R., "Strategic supplier selection in the added-value perspective: A CI approach”, Information Sciences, 2007, 177, 1160-1179.

Flynn, B and Flynn, E., "Synergies between supply chain management and quality management: emerging implications”, International Journal of Production Research, 2005, 43, 3421-3436.

Garvin, D.A., "Competing on the eight dimensions of quality”, Harvard Business Review, 1987, 6, 101-109.

González-Benito, J. and Dale, B., “Quality and Reliability Assurance Practices in the Spanish Auto Components Industry: A Study of Implementation Patterns”, European Journal of Purchasing and Supply Management, 2001, 7, 187-196. 
González-Benito, J., Martínez-Lorente, A. and Dale, B., “A Study of the Purchasing Management System with respect to Total Quality Management”, Industrial Marketing Management, 2003, 32, 443-454.

Fynes, B., Voss, C. and Búrca, S., "The impact of supply chain relationship dynamics on manufacturing performance”, International Journal of Operations \& Production Management, 2005, 25 (1),6-20.

Hsu, C and Wallace, A., “An Industrial Network flow information integration model for supply chain management and intelligen transportation”, Enterprise Information System, 2007, 1, 327-351.

Johansen, J. and Vahlne, J., “The internationalization process of the firm - a model of knowledge development and increasing foreign market commitments”, Journal of International Business Studies, 1977, 8, 23-32.

Johnson, G. and Scholes, K. Exploring Corporate Strategy, 2000, Prentice Hall, Madrid.

Kaufmann, L. and Carter, C., "International supply relationships and non financial performance-a comparison of US and German practices”, Journal of Operations Management, 2006, 24, 653-675.

Kaynak, $\mathrm{H}$ and Hartley, J., “A replication and extension of quality management into the supply chain”, Journal of Operations Management, 2008, 26, 468-489.

Lambert, D., Emmelhainz, M. and Gardner, J., "Developing and implementing supply chain partnerships”, The International Journal of Logistics Management, 1996, 7, 117.

Liker, J. and Choi, T, "Building Deep Supplier Relationships”, Harvard Business Review, December, 2004, 82, 104-113.

Li, S., Ragu-Nathan, B., Ragu-Nathan, T. and, Rao, S., "The impact of supply chain management practices on competitive advantage and organizational performance”, Omega, 2006, 32, 107-124.

MacCallum, R. and Browne, M., "The use of causal indicators in covariance structure models: Some practical issues”, Psychological Bulletin, 1993, 114, 533-541.

Martínez-Costa, M., Martínez-Lorente, A. R, Does quality management foster or hinder innovation? An empirical study of Spanish companies. Total Quality Management \& Business Excellence, 2008, 19, 209-221.

Matthews, C.R., “Linking the supply chain to TQM”, Quality Progress, 2006, 39, 2935. 
Merino, J., “Quality management practices and operational performance: empirical evidence for Spanish industry”, International Journal of Production Research, 2003, 41, 2763-2786.

Morgan, R and Hunt, S, “The commitment-trust theory of relationship marketing”, Journal of Marketing, 1994, 58, 20-38.

Nair, A. and Prajogo, D., "Internalization of ISO 9000 Standards: The Antecedent Role of Functionalist and Institutionalist Drivers and Performance Implications”, International Journal of Production Research, 2009, 41, 4545-4568.

Narasimhan, R. and Carter, J., "Linking business unit and material sourcing strategies”, Journal of Business Logistics, 1998, 19, 155-179.

Nunnally, J. and Bernstein, I. Psychometric Theory, 1984, Third Edition, New York, McGraw-Hill

Palaniswarni, S. and Lingaraj, B., "Procurement and vendor management in the global environment”, International Journal of Production Economics, 1994, 35, 171-176.

Pfohl, H. and Large, R., "Eastern-Western supplier-customer relationships in agricultural machinery industry: results of an empirical investigation in the Czech Republic, Hungary, Romania, Ukraine, and Germany”, European Journal of Purchasing \& Supply Management, 1997, 3, 177-187 .

Podsakoff, N., Shen, W. and Podsakoff, P., "The role of formative measurement models in strategic management research: review, critique, and implications for future research”, Research Methodology in Strategy and Management, 2006, 3, 197-252.

Salmi, A., "Organising international supplier relations: an exploratory study of Western purchasing in China”, Journal of Purchasing and Supply Management, 2006, 12, 197-208.

Sánchez-Rodríguez, C. and Martínez-Lorente, A., “Quality management practices in the purchasing function: an empirical study”, International Journal of Operations \& Production Management, 2004, 24, 666-87.

Saraph, J., Benson, P. and Schroeder, R., “An instrument for measuring the critical factors of quality management”, Decision Sciences, 1989, 20, 810-829.

Sila, I., "Examining the Effects of Contextual Factors on TQM and Performance Through the Lens of Organizational Theories: An Empirical Study”, Journal of Operations Management, 2007, 25, 83-109.

Skarmeas, D., Katsikeas, C., Spyropoulou, S. and Salehi-Sangari, E., "Market and supplier characteristics driving distributor relationship quality in international 
marketing channels of industrial products”, Industrial Marketing Management, 2008, 37, 23-36.

Sroufe, R and Curkovic, S., “An Examination of ISO 9000: 2000 and Supply Chain Quality Assurance”, Journal of Operations Management, 2008, 26, 503-520.

Steinle, C. and Schiele, H., "Limits to global sourcing? Strategic consequences of dependency on international suppliers: cluster theory, resource-based view and case studies’, Journal of Purchasing and Supply Management, 2008, 14, 3-14.

Sven Ivens, B., Pardo, C. And Tunisini, A. "Organizing and integrating marketing and purchasing in business markets: An introduction to the special issue, issues and implications”, Industrial Marketing Management, 2009, 38, 851-856.

Terpstra , V. and Sarathy, R., International Marketing, 2000, Dryden Press, $8^{\text {th }}$ Edn.

Yeung, A. 2008, "Strategic Supply Management, Quality Initiatives and Organizational Performance”, Journal of Operations Management, 2008, 26, 490-502. 
Table I. Quality Assurance Practices Variables. Descriptive statistics

\begin{tabular}{lrrrc}
\hline & Mean & St. dev. & \\
\hline Internal Quality Practices & 3.005 & 1.245 & \\
\hline External Quality Practices index (1 to 5 scale) & 3.859 & 0.839 & VIF \\
\hline We strive to establish long-term relationships with suppliers & 4.278 & 0.622 & 1.194 \\
Quality is a key element to select suppliers & 4.180 & 0.877 & 1.338 \\
Our suppliers are actively involved in our new product & 3.775 & 1.226 & 1.328 \\
development process & 3.480 & 1.543 & 1.259 \\
We periodically evaluate our suppliers through audits. & 3.593 & 1.410 & 1.410 \\
We agree with our suppliers specific certification for quality & & &
\end{tabular}

Table II. Supplier Localization and Control Variables. Descriptive Statistics

\begin{tabular}{lrr}
\hline & Mean & St. Dev. \\
\hline $\begin{array}{l}\text { Percentage of purchases of raw materials and components in low } \\
\text { labour cost countries }\end{array}$ & 10.087 & 19.987 \\
Percentage of purchases of raw materials and components in & 70.696 & 28.829 \\
Spain & 201.589 & 504.139 \\
Number of workers in the plant & 0.112 & \\
Part of a multinational firm & 6.751 & 1.864 \\
Advanced Manufacturing Technologies implementation (0-10 & & \\
scale) & 4.117 & 0.830 \\
Competition in the market & 0.590 & \\
Strategy of the plant focused on quality & 0.297 & \\
Strategy of the plant focused on cost & &
\end{tabular}


Table III. Correlation Matrix

$\begin{array}{llllllll}2 & 3 & 4 & 5 & 6 & 7 & 8 & 9\end{array}$

1. Internal Quality Assurance 1

2. External Quality Assurance

$0.440 * * * \quad 1$

3. Proportion of input purchase in Spain

$-0.113^{* *}-0.099 \quad 1$

4. Proportion of input purchase in low labour cost countries

$0.148 * * \quad 0.043 \quad-0.499 * * 1$

5. Size

$\begin{array}{lllll}0.107 * * & 0.128 * * & -0.082 & 0.016 & 1\end{array}$

6. Multinational

7. Competition

$0.086-0.026$

$-0.070 \quad-0.016 \quad-0.016$

$0.084 * 0.032 \quad 1$

8. Advanced Manufacturing Technologies

$\begin{array}{llllllll}0.015 & 0.139 * * & -0.053 & -0.021 & 0.120 * * & 0.057 & 0.097 & 1\end{array}$

9. Strategy focused on quality

$0.028 \quad 0.215^{* *} \quad 0.009$

0.008

$-0.057$

$-0.058-0.052$

10. Strategy focused on cost

$-0.011 \quad 0.161^{* *}-0.025$

$0.015 \quad 0.062$

$\begin{array}{ll}-0.008 & 0.067\end{array}$

$-0.511$

** $\mathrm{p}<0.05, * * * \mathrm{p}<0.01$ 


\begin{tabular}{|c|c|c|}
\hline & Model 1 & Model 2 \\
\hline \multirow[t]{2}{*}{$\mu_{1}$} & $-1.522 * * *$ & $-12.613^{*}$ \\
\hline & $(0.332)$ & $(6.660)$ \\
\hline \multirow[t]{2}{*}{$\mu_{2}$} & $-0.576^{*}$ & $-11.541^{*}$ \\
\hline & $(0.322)$ & $(6.661)$ \\
\hline \multirow[t]{2}{*}{$\mu_{3}$} & -0.285 & $-11.226^{*}$ \\
\hline & $(0.321)$ & $(6.661)$ \\
\hline \multirow[t]{2}{*}{ Proportion of input purchase in Spain } & -0.260 & -0.007 \\
\hline & $(0.386)$ & $(0.412)$ \\
\hline \multirow[t]{2}{*}{ Proportion of input purchase in low labour cost countries } & $1.665^{* *}$ & $1.494^{* *}$ \\
\hline & $(0.654)$ & $(0.672)$ \\
\hline \multirow[t]{2}{*}{ Size } & & $0.001^{*}$ \\
\hline & & $(0.001)$ \\
\hline \multirow[t]{2}{*}{ Multinational } & & 0.264 \\
\hline & & $(0.346)$ \\
\hline \multirow[t]{2}{*}{ Competition } & & $0.240^{*}$ \\
\hline & & $(0.128)$ \\
\hline \multirow[t]{2}{*}{ Advanced Manufacturing Technologies } & & $0.012^{* *}$ \\
\hline & & $(0.055)$ \\
\hline \multirow[t]{2}{*}{ Strategy focused on quality } & & $0.403^{* * *}$ \\
\hline & & $(0.319)$ \\
\hline \multirow[t]{2}{*}{ Strategy focused on cost } & & 0.131 \\
\hline & & $(0.344)$ \\
\hline Pseudo $\mathrm{R}^{2}$ & 0.047 & 0.140 \\
\hline $\mathrm{X}^{2}$ & $18.542 * * *$ & $59.776^{* * *}$ \\
\hline
\end{tabular}

Sector dummies are controlled for in the second model

Standard errors in brackets 
Table V. Results of the OLS Model for External Quality Assurance

\begin{tabular}{|c|c|c|}
\hline & Model 1 & Model 2 \\
\hline \multirow[t]{2}{*}{ Constant } & $4.072^{* * *}$ & $3.203^{* * *}$ \\
\hline & $(0.125)$ & $(0.346)$ \\
\hline \multirow[t]{2}{*}{ Proportion of input purchase in Spain } & -0.169 & -0.120 \\
\hline & $(0.151)$ & $(0.164)$ \\
\hline \multirow[t]{2}{*}{ Proportion of input purchase in low labour cost countries } & 0.041 & 0.025 \\
\hline & $(0.217)$ & $(0.237)$ \\
\hline \multirow[t]{2}{*}{ Size } & & $0.014 *$ \\
\hline & & $(0.008)$ \\
\hline \multirow[t]{2}{*}{ Multinational } & & 0.191 \\
\hline & & $(0.129)$ \\
\hline \multirow[t]{2}{*}{ Competition } & & 0.036 \\
\hline & & $(0.049)$ \\
\hline \multirow[t]{2}{*}{ Advanced Manufacturing Technologies } & & $0.051^{* *}$ \\
\hline & & $(0.022)$ \\
\hline \multirow[t]{2}{*}{ Strategy focused on quality } & & $0.357 * * *$ \\
\hline & & $(0.130)$ \\
\hline \multirow[t]{2}{*}{ Strategy focused on cost } & & 0.008 \\
\hline & & $(0.140)$ \\
\hline $\mathrm{R}^{2}$ & 0.005 & 0.159 \\
\hline $\mathrm{F}$ & 1.002 & $3.536 * * *$ \\
\hline \multicolumn{3}{|l|}{$\mathrm{p}<0.10, * * \mathrm{p}<0.05, * * * \mathrm{p}<0.01$} \\
\hline \multicolumn{3}{|l|}{ Sector dummies are controlled for in the second model } \\
\hline
\end{tabular}

